Reconsidering Israel and Judah 


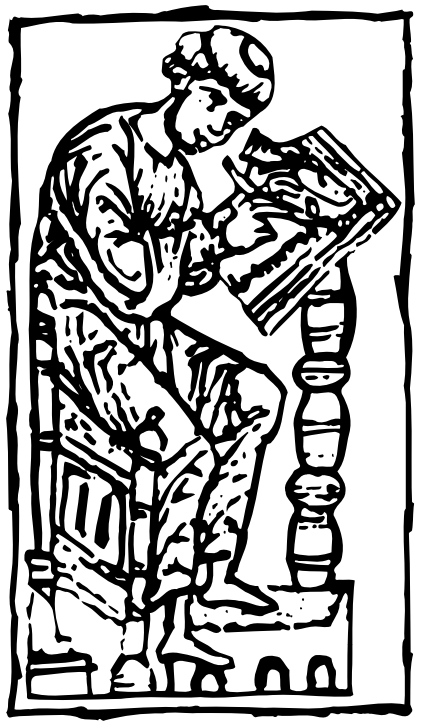

\title{
Sources for Biblical and Theological Study
}

\author{
General Editor: \\ David W. Baker \\ Ashland Theological Seminary
}

1. The Flowering of Old Testament Theology: A Reader in Twentieth-Century Old Testament Theology, 1930-1990

edited by Ben C. Ollenburger, Elmer A. Martens, and Gerhard F. Hasel

2. Beyond Form Criticism: Essays in Old Testament Literary Criticism edited by Paul R. House

3. A Song of Power and the Power of Song: Essays on the Book of Deuteronomy edited by Duane L. Christensen

4. "I Studied Inscriptions from before the Flood": Ancient Near Eastern, Literary, and Linguistic Approaches to Genesis 1-11

edited by Richard S. Hess and David Toshio Tsumura

5. "The Place Is Too Small for Us": The Israelite Prophets in Recent Scholarship edited by Robert P. Gordon

6. Community, Identity, and Ideology: Social Science Approaches to the Hebrew Bible

edited by Charles E. Carter and Carol L. Meyers

7. Israel's Past in Present Research: Essays on Ancient Israelite Historiography edited by V. Philips Long

8. Reconsidering Israel and Judah: Recent Studies on the Deuteronomistic History edited by Gary N. Knoppers and J. Gordon McConville 


\title{
Reconsidering \\ Israel and Judah
}

Recent Studies on the

Deuteronomistic History

\author{
edited by \\ Gary N. Knoppers \\ and \\ J. Gordon McConville
}

Eisenbrauns

Winona Lake, Indiana

2000 
(C) 2000 by Eisenbrauns.

All rights reserved.

Printed in the United States of America.

Library of Congress Cataloging-in-Publication Data

Reconsidering Israel and Judah : recent studies on the Deuteronomistic history / edited by Gary N. Knoppers and J. Gordon McConville

p. cm. - (Sources for biblical and theological study)

Includes bibliographical references (p. ) and index.

ISBN 1-57506-037-X (cloth : alk. paper)

1. Bible. O.T. Former Prophets-Criticism, interpretation, etc.

2. Deuteronomistic history (Biblical criticism) 3. Jews-History-To 586 B.C.-Historiography. I. Knoppers, Gary N., 1956-

II. McConville, J. G. (J. Gordon) III. Series.

BS1286.5 .R43 2000

$222^{\prime} .06-\mathrm{dc} 21$

00-035326

CIP

The paper used in this publication meets the minimum requirements of the American National Standard for Information Sciences-Permanence of Paper for Printed Library Materials, ANSI Z39.48-1984.@ 
Dedicated to our children,

Theresa Maria and David Joel

Knoppers

and

Alistair Gordon, Carys Elizabeth, Andrew Samuel Walter, and Claire Alexandra McConville 
This page intentionally left blank. 